\title{
Transformasi Produk Sekunder Pengolahan Minyak Parede Sebagai Produk Sambel Kerak Minyak
}

\author{
Andi Muhamad Iqbal Akbar Asfar*1, M Yasser², Andi Nurul Istiyana ${ }^{3}$, Andi Muhammad Irfan Taufan \\ Asfar $^{4}$, Ady Kurnia $^{5}$ \\ 1Program Studi Teknik Kimia, Jurusan Teknik Kimia, Politeknik Negeri Ujung Pandang \\ ${ }^{2}$ Program Studi Analisis Kimia, Jurusan Teknik Kimia, Politeknik Negeri Ujung Pandang \\ ${ }^{3}$ Program Studi Akuntansi, Jurusan Akuntansi, Politeknik Negeri Ujung Pandang \\ 4Program Studi Pendidikan Matematika, Jurusan MIPA, STKIP Muhammadiyah Bone \\ 5Program Studi Manajemen, Fakultas Ekonomi, Universitas Indonesia Timur \\ *e-mail: andiifalasfar@gmail.com*1, myasser@poliupg.ac.id ${ }^{2}$, andinurulistiyana@poliupg.ac.id 3, \\ tauvanlewis00@gmail.com ${ }^{4}$, adykurnia@uit.ac.id ${ }^{5}$
}

\begin{abstract}
Coconut oil processing or what is known by the Bugis people in South Sulawesi, namely Parede Oil, leaves a secondary product in the form of oil crust. This oil crust is not fully utilized, especially as a product that can increase its selling value. Therefore, this community service in the form of a community partnership program conducts training in processing oil crust into oil crust sauce. Until now, this product has survived with a shelf life of more than 4 months without the addition of any preservatives. This product is packaged in a chili pot with a net weight of 60 grams. This program has succeeded in improving the skills of partners, namely the PKK Latellang Village, Patimpeng District, Bone Regency, South Sulawesi Province, in utilizing oil crust to become oil-based chili sauce which has high economic value.
\end{abstract}

Keywords: Coconut Oil Crust, Oil Crust Sausage, Secondary Product.

\begin{abstract}
Abstrak
Pengolahan Minyak Kelapa atau yang dikenal oleh masyarakat Bugis di Sulawesi Selatan yaitu Minyak Parede, menyisahkan produk sekunder berupa kerak minyak. Kerak minyak ini kurang dimanfaatkan secara maksimal khususnya menjadi produk yang bisa meningkatkan nilai jualnya. Oleh karena itu, pengabdian masyarakat ini dalam bentuk program kemitraan masyarakat melakukan pelatihan pengolahan kerak minyak menjadi sambel kerak minyak. Hingga saat ini produk ini masih bertahan dengan masa daya simpan melebihi 4 bulan tanpa adanya penambahan pengawet apapun. Produk ini dikemas dalam bentuk pot sambel dengan berat bersih 60 gram. Program ini telah berhasil meningkatkan keterampilan mitra yaitu Ibu PKK Desa Latellang Kecamatan Patimpeng Kabupaten Bone Propinsi Sulawesi Selatan dalam memanfaatkan kerak minyak menjadi sambel kerak minya yang memiliki nilai ekonomis yang tinggi.
\end{abstract}

Kata kunci: Kerak Minyak Kelapa, Sambel Kerak Minyak, Produk Sekunder

\section{PENDAHULUAN}

Kelapa adalah salah satu jenis tanaman yang termasuk ke dalam suku pinang-pinangan (arecaceae). Semua bagian pohon kelapa dapat dimanfaatkan, mulai dari bunga, batang, pelepah, daun, buah, bahkan akarnya pun dapat dimanfaatkan. Batang pohon kelapa merupakan batang tunggal, tetapi terkadang dapat bercabang. Tinggi pohon kelapa dapat mencapai lebih dari $30 \mathrm{~m}$. Daun kelapa tersusun secara majemuk, menyirip sejajar tunggal, berwarna kekuningan jika masih muda dan berwarna hijau tua jika sudah tua. Tumbuhan ini diperkirakan berasal dari pesisir Samudera Hindia di sisi Asia, namun kini telah menyebar luas di seluruh pantai tropika dunia. Buah kelapa dari sabut, cangkang hingga isinya memberikan manfaat yang melimpah kepada manusia, misalnya cangkang kelapa dapat dibakar untuk menghasilkan asap cair (Nurlia et al, 2020). Selain itu, buah kelapa jika diolah aka menghasilkan minyak kelapa dengan mengolah daging buah kelapa segar atau dari kopra. Tanaman ini sangat banyak dimanfaatakan dalam kehidupan manusia termasuk batok kelapa dapat damnafaatkan sebagai asapa cair (Salam dan Syahrizal, 2018) dan dagingnya dimanafaatkan untuk pembuatan minyak. Proses untuk membuat minyak kelapa dari daging buah kelapa segar dikenal dengan nama proses basah (wet process), karena pada proses ini ditambahkan air untuk mengekstraksi minyak. Sedangkan pembuatan 
minyak kelapa dengan bahan baku kopra dikenal dengan proses kering (dry process) (Azis, Olga dan Sari, 2017).

Pada tahun 2017 luas areal pertanaman kelapa Indonesia hanya 3,59 juta hektar, menurun dibanding tahun 2007 yang sudah mencapai 3,80 juta hektar. Hal ini antara lain disebabkan oleh pengalihan fungsi lahan perkebunan kelapa menjadi permukiman dan infrastruktur transportasi. Selain itu, laju usaha peremajaan kelapa lebih lambat dibanding penebangan kelapa tua. Rendahnya pendapatan petani antara lain disebabkan oleh rendahnya nilai jual kelapa dalam bentuk produk primer seperti kelapa butiran dan kopra (Karaouw, Santoso dan Maskromo, 2017). Salah satu desa yang di Indonesia tepatnya di Desa Latellang Dusun Latellang merupakan salah satu desa di Kecamatan Patimpeng Kabupaten Bone Provinsi Sulawesi Selatan yang merupakan sentra pengolah minyak kelapa. Desa ini dijadikan sebagai lokasi Program Kemitraan Masyarakat (PKM). Sebagai desa Swakarya, luas area Kecamatan Patimpeng seluas 130,47 $\mathrm{km}^{2}$, khusus untuk Desa Latellang seluas $9 \mathrm{~km}^{2}$ atau sekitar 6,9\% dari luas total Kecamatan Patimpeng (BPS Kecamatan Patimpeng, 2019). Daerah ini sebagaimana layaknya daerah-daerah yang ada di Sulawesi Selatan, banyak ditumbuhi kelapa.

Minyak Parede merupakan istilah yang digunakan masyarakat di Sulawesi Selatan sebagai santan yang dipanaskan hingga menjadi minyak, berbau khas dan beraroma tajam yang dapat mengugah selera makan. Minyak Parede sangat populer di Sulawesi Selatan dan beberapa propinsi lainnya termasuk Sulawesi Utara, Sulawesi Tenggara hingga Sulawesi Tengah dan Sulawesi Barat yang disebabkan aroma khas yang mengugah selera ketika makanan digoreng atau dicampurkan dengan Minyak Parede. Namun, pada proses pembuatan Minyak Parede menyisahkan produk sekunder berupa kerak minyak yang masih kurang dimanfaatkan untuk dikomersilkan yang tidak kalah pula aroma khasnya serta dapat dibuat panganan lain hingga sambal khas berbahan dasar kerak minyak dari Minyak Parede ini. Akan tetapi, para pembuat atau pengolah Minyak Parede hanya memanfaatkan/dikonsumsi secara pribadi (rumah tangga) sebagai tambahan lauk atau diolah dengan bahan lain. Padahal, Minyak kelapa dapat diolah menjadi beberapa produk termasuk minyak kelapa murni termasuk VCO dan sambel khas.

Kandungan minyak pada daging buah kelapa tua sebanyak 34,7\% (Anwar dan Salima, 2016). Pada waktu daging buah kelapa diparut, sel-selnya akan rusak dan isi sel dengan mudah dikeluar kan dalam wujud emulsi berwarna putih yang dikenal dengan santan. Santan mengandung minyak sebanyak 50\%. Sisa minyak yang lain dapat di peroleh dengan penambahan air dan pemerasan kedua dan ketiga (Marlina et al., 2017). Permintaan minyak kelapa sedikit lebih tinggi dibandingkan dengan minyak dan lemak lain karena memiliki ciri khas dan kelebihan yang membuatnya cocok untuk bahan baku industri pangan khususnya dan kimia pada umumnya dimana produksi minyak kelapa selalu meningkat sejalan dengan kenaikan kebutuhan minyak kelapa oleh masyarakat (Muharun dan Apriyantono, 2014). Minyak kelapa murni banyak dimanfaatkan untuk menyembuhkan berbagai macam penyakit karena kandungan asam lemak yang ada di dalamnya. Proses pembuatan minyak kelapa diusahakan sedemikian rupa sehingga tidak merusak asam lemak yang terdapat di dalamnya (Latipah dan Syarifuddin, 2019).

Minyak kelapa murni dengan kandungan utama asam laurat dan asam kaprat yang sangat bermanfaat bagi kesehatan tubuh dimana asam laurat di dalam tubuh manusia akan dirubah menjadi monolaurin yang dapat menanggulangi berbagai serangan virus seperti HIV, herpes, influenza dan berbagai bakteri pathogen. Dengan sifatnya itu, monolaurin dapat menanggulangi serangan virus-virus seperti HIV, herpes simplex virus-1 (HSV-1), vesicular stomatitis virus (VSV), visna virus, cytomegalovirus (CMV), influenza, dan berbagai bakteri patogen termasuk listeria monocytogenes dan helicobacter pyloryd, serta protozoa seperti giadia lamblia. Sifat-sifat antiinfeksi yang dipunyai asam-asam lemak bergantung pada struktur kimianya, misalnya monoglyserides bersifat antiinfeksi. Sedangkan diglycerides dan triglycerides bersifat tidak antiinfeksi (Haerani, 2010).

Asam laurat merupakan lemak jenuh berantai sedang atau Medium Chain Fatty Acid (MCFA) yang berfungsi meningkatkan metabolisme dalam tubuh sehingga dapat menambah energi dan efek stimulasi dan mengontrol berat badan. Persentase MCFA pada minyak kelapa 
adalah asam laurat 48\%, asam kaprilat $8 \%$, asam kaprat 7\% dan lainnya merupakan asam asam yang bermanfaat serta dapat mengobati sejumah penyakit seperti abses, alopecia, amenorrhea, asma, bronchitis, TBC, tumor, sipilis, dan luka luka (Yuniwati, 2018:152). Berdasarkan analisis standar komposisi asam-asam lemak yaitu asam laurat (43-53\%); miristat (16-21\%); palmitat (7,5-10\%); kaprat (4,5-8,0\%); oktanoat/kaprilat (5- 10\%); oleat (4-10\%); stearat (2-4\%); linoleat (1-2,5\%) dan kaproat (0,4-0,6\%). Sebagian besar komposisi VCO merupakan Asam lemak jenuh. Asam lemak jenuh pada VCO terdiri dari rantai pendek dan menengah, di mana dalam tubuh, asam lemak tersebut mudah dicerna dan diserap oleh usus karena ukuran molekulnya relatif kecil sehingga asam lemak tersebut langsung dibakar oleh tubuh untuk memproduksi energi (Aprilasani dan Adiwarna, 2014).

Pemanfaatan kerak minyak dari pemrosesan minyak kelapa masih kurang dimanfaatkan secara maksimal dan tentunya memiliki manfaat yang sama dengan minyak kelapa yang diolah (Minyak Parede) dari segi khasiatnya. Oleh karena itu, pelaksanaan pengbadian ini bertujuan untuk menguatkan dan membangkitkan kembali sentra pembuatan Minyak Parede yang sebagian masyarakat pembuat Minyak Parede di Desa Latellang yang mulai meninggalkan pembuatan produk ini sebab masyarakat merasakan tingginya biaya operasional dalam pembuatannnya yang menggunakan waktu pemasakan selama berjam-jam serta bahan bakar yang digunakan selama prosesnya. Selain itu, harga jual tidak dapat menutupi biaya operasional yang telah dikeluarkan. Oleh karena itu, masyarakat khususnya Ibu PKK Desa Latellang dapat menjadi penghubung dalam peningkatan kualitas dan kemampuan menumbuhkembangkan pemanfaatan produk sekunder untuk lebih bermanfaat dan memiliki nilai ekonomis. Sebagai contoh dalam pengabdian ini yaitu memanfaatkan kerak minyak hasil pengolahan Minyak Parede menjadi Sambel Kerak Minyak yang lebih memiliki nilai jual untuk mendukung tambahan pendapatan dari hasil penjualan Minyak Parede. Sehingga, dampaknya akan menumbuhkan antusiasme pengolah Minyak Parede dalam membuat dan mengomersilkan produk Minyak Parede ini kembali khususnya dalam mengolah produk sekunder yaitu Kerak Minyak Parede yang masih dapat dijual menjadi produk bernilai ekonomis tinggi.

\section{METODE}

Pelaksanaan program kemitraan ini dilakasanakan dalam bentuk pelatihan dan pendampingan pada mitra. Mitra dalam program ini adalah Ibu PKK Desa Latellang Kecamatan Patimpeng Kabupaten Bone Propinsi Sulawesi Selatan. Jumlah anggota mitra sebanyak 5 orang yang memiliki kualifikasi pendidikan SMA dan SMP. Uraian pelaksanaan PKM ini sebagai berikut:

a. Pelatihan

Pelatihan dilaksanakan untuk memberikan informasi, peningkatan keterampilan dan kemampuan mentransformasikan produk sekunder dari pengolahan Minyak Parede menjadi Sambel Kerak Minyak. Pelaksanaan pelatihan dilaksanakan secara society parcipatory, yakni mitra terlibat secara penuh dalam semua kegiatan dan implikasinya mitra mampu melakukan transformasi kerak minyak menjadi sambel kerak minyak secara by doing (Yasser et al., 2020; Asfar et al., 2019).

Pelatihan dilaksanakan dengan beberapa tahapan yaitu penyiapan bahan baku berupa kelapa tua, pemarutan kelapa, pemerasan santan, pemisahan skim, pendidihan skim, dan pemisahan minyak dan kerak, dan pembuatan sambel kerak minyak.

b. Pendampingan

Pendampingan dilaksanakan untuk bahan evaluasi bagi tim pelaksana akan kemampuan mitra secara mandiri melaksanakan dan memproduksi pembuatan produk seperti yang dilatihkan kepada mitra ataupun terjadi pengembangan proses dari mitra. Mitra diharapkan pada tahapan ini berkeinginan untuk senantiasa melakukan knowledge sharing kepada tim pelaksana akan kendala-kendala (menemukenali permasalahan yang dtemui 
mitra) atau pengembangan kemampuan olah mitra selama memproduksi sambel kerak minyak (Yasser et al., 2020).

Pada tahapan ini pula dilakukan pengambilan data secara observasi menggunakan observational sheet untuk menganalisis pengetahuan, keterampilan, dan kemampuan pengembangan mitra dalam mentransformasikan kerak minyak dari Minyak Parede menjadi Sambel Kerak Minyak. Ada tiga komponen analisis yaitu pengetahuan mitra akan produk sekunder yaitu kerak minyak, keterampilan membuat sambel kerak minyak, dan keterampilan melakukan pengemasan produk sambel kerak minya. Selain itu, untuk menjamin keberlangsungan pemanfaatan kerak Minyak Parede ini sebagai Sambel Kerak Minyak, maka akan dilakukan pendampingan kepada mitra.

\section{HASIL DAN PEMBAHASAN}

Pengabdian masyarakat dalam bentuk Program Kemitraan Masyarakat ini difokuskan kepada peningkatan pengetahuan dan keterampilan mitra dalam mengolah produk sekunder brupa kerak minyak hasil dari pengolahan Minyak Parede yang menyisahkan kuantitas kerak minyak setelah pengolahan untuk dimanfaatkan secara maksimal.

Pelaksanaan transformasi kerak minyak menjadi Sambel Kerak Minyak dapat diuraikan menjadi beberapa tahap hasil pelaksanaan Program Kemitraan Masyarakat ini yaitu

a. Pelatihan Pembuatan Sambel Kerak Minyak

Pada tahapan ini tim mendemonstrasikan cara pembuatan sambel kerak minyak dan mitra yang melaksanakan secara penuh. Pelaksanaan dengan mitra melakukan secara by doning akan menambah keterampilan dalam membuat sambel kerak minyak.

Pembuatan sambel kerak minyak dilakukan dengan melakukan pemilahan buah kelapa tua. Buah kelapa yang dipilih benar-benar tua untuk mengahsilkan Minyak Parede yang baik serta kerak minyak yang beraroma khas. Sambel kerak minyak yang diperoleh dari hasil pengolahan Minyak Parede dipisahkan kemudian ditambahkan dengan bahan-bahan berupa cabe rawit, bawang putih, dan bawang merah serta garam dan sedikit gula.

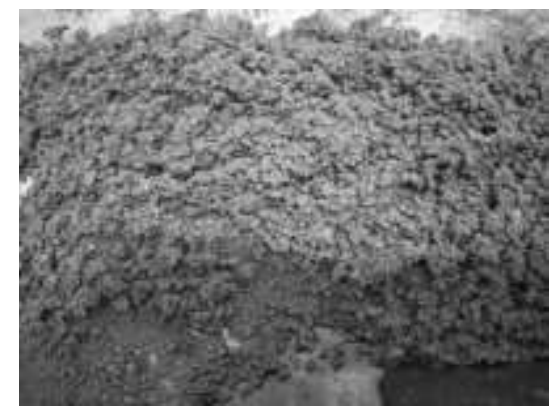

Gambar 1. Pemisahan Kerak Minyak dengan Minyak Parede

Mitra sangat antusias dalam pelatihan ini sebab selama ini kerak minyak hanya dijadikan tambahan lauk saja tanpa diproses lagi untuk dijadikan makanan atau sambel yang ternyata bisa menghasilkan nilai jual yang tinggi dibandingkan hanya dikonsumsi saja.

Satu keunggulan yang diperoleh mitra adalah Sambel Kerak Minyak memiliki daya simpan yang jauh lebih lama dari ekspektasi mitra yaitu lebih dari 4 bulan. Sambel yang masih disimpan oleh mitra untuk observasi daya simpan produk masih memiliki aroma yang khas seperti awal pembuatan serta tidak ada penampakan visual akan adanya cendawan yang menandakan produk telah rusak. 


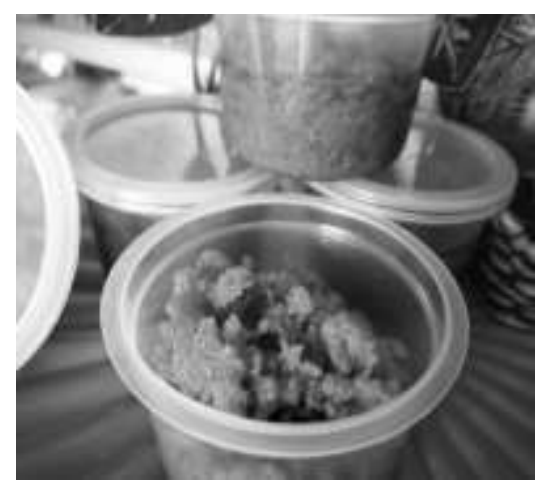

Gambar 2. Pemisahan Kerak Minyak dengan Minyak Parede

b. Pendampingan Mitra

Pendampingan mitra dilakukan untuk mengevaluasi sejauh mana mitra dapat mandiri melakukan pembuatan Sambel Kerak Minyak termasuk kendal-kendala yang dihadapi mitra (Asfar et al., 2020). Beberapa kendala mitra yang ditemui adalah higenis produksi yang perlu diperbaiki dan ditingkatkan. Higenis produksi dalam pembuatan Sambel Kerak Minyak memiliki indikator jika terjadi kesalahan maupun mitra tidak menerapkan proses higenis dalam pembuatannya seperti munculnya cendawan hanya dalam dua hari. Selain itu, penggunaan air dalam pembuatan sambel sangat tidak disarankan, tetapi tim pelaksana mewajibkan kepada mitra untuk menggunakan minyak sebagai pengganti air ketika akan membuat Sambel Kerak Minyak khususnya ketika menghaluskan bumbu-bumbu pembuatan sambel menggunaka blender. Bumbu-bumbu yang digunakan sebaiknya telah kering dengan sempurna tanpa kelihatan basah karena adanya air yang masih melekat pada bawang putih, bawang merah dan cabe rawit.

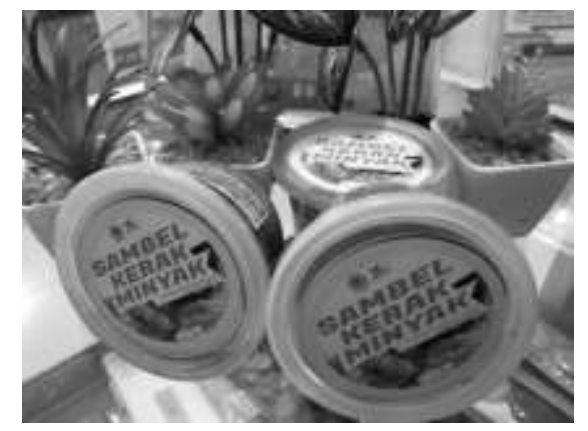

Gambar 3. Sambel Kerak Minyak

Sekaitan dengan kemampuan mitra dalam proses pengemasan produk, mitra sangat cepat mengembangkan keterampilannya dalam melakukan pengemasan termasuk melakukan labelisasi produk. Mitra mengusulkan untuk kedepannya tidak hanya menggunakan pot sambel sebagai wadah kemasan, tetapi juga akan menggunakan pouch untuk kapasitas sambel yang lebih besar.

c. Analisis Hasil Pelaksanaan PKM

Hasil evaluasi terhadap mitra mengenai peningkatan keterampilan dalam mengenal manfaat minyak parede termasuk pemanfaatan kerak minyak menjadi sambel serta peningkatan mitra dalam proses pembuatan hingga pengemasan dilakukan dengan analisa menggunakan observational sheet yang diisi oleh tim berdasarkan hasil pengamatan kepada mitra setelah pelaksanaan PKM di Desa Latellang. Hasil olah data dari observational Sheet dapat dilihat pada Tabel 1. 
Tabel 1. Analisis Peningkatan Pengetahuan dan Keterampilan Mitra

\begin{tabular}{cccc}
\hline Indikator & $\begin{array}{c}\text { Sebelum Pelaksanaan } \\
\text { PKM (\%) }\end{array}$ & $\begin{array}{c}\text { Setelah Pelaksanaan } \\
\text { PKM (\%) }\end{array}$ & $\begin{array}{c}\text { Persentase } \\
\text { Peningkatan (\%) }\end{array}$ \\
\hline $\begin{array}{c}\text { Informasi } \\
\text { Pemanfaatan Produk } \\
\text { Sekunder Minyak } \\
\text { Parede }\end{array}$ & 30 & 75 & 45 \\
$\begin{array}{c}\text { Kemampuan Proses } \\
\text { Pembuatan Sambel } \\
\text { Kerak Minyak }\end{array}$ & 20 & 80 & 60 \\
Kemampuan & 0 & 80 & 80 \\
Pengemasan Produk & & & \\
\hline
\end{tabular}

Hasil analisis peningkatan keterampilan mitra sangat signifikan. Kemampuan mitra dalam memiliki informasi akan manfaat serta pemanfataan produk sekunder Minyak Parede sebesar 45\%. Mitra dalam hal ini, telah mengetahui manfaat akan mengonsumsi Minyak Parede dibandingkan dengan minyak lainnya serta mitra juga memiliki pengetahuan tambahan bahwa kerak minyak sebagai produk sekunder dari hasil pengolahan Minyak Parede memiliki kegunaan dan peluang untuk dikembangkan menjadi Sambel Kerak Minyak.

Kemampuan proses pembuatan Sambel Kerak Minyak oleh mitra memberikan kontribusi peningkatan keterampilan kepada mitra sebesar $60 \%$. Kemampuan proses ini meliputi kemampuan mitra melakukan pemisahan air santan dan skim serta melakukan pendidihan yang benar agar menghasilkan produk Minyak Parede yang tidak beraroma gosong, tetapi beraroma khas Minyak Parede. Selain itu, cara pendidihan yang baik akan menghasilkan pula kerak minyak yang baik dengan penampakan visual yaitu berwarna coklat muda keputihan. Selain itu, mitra pada awalnya tidak mengetahui cara membuat sambel dari kerak minyak hanya mengonsumsi saja atau menambahkan cabe atau bahan lainnya untuk tambahan lauk saja, saat ini mitra telah mampu membuat Sambel Kerak Minyak dari transformasi kerak minyak hasil samping Minyak Parede. Mitra juga telah mampu melakukan higenis produksi dan preparasi bahan baku pembuatan sambel yaitu bawang putih, bawang merah, dan cabe rawit termasuk cara memastikan bahan-bahan tersebut telah kering sempurna setelah dibersihkan.

Komponen analisis ketiga adalah kemampuan pengemasan produk oleh mitra. Kemampuan ini menunjukkan peningkatan yang signifikan dengan besarnya persentase peningkatan keterampilan mitra sebesar $80 \%$. Peningkatan ini disebabkan mitra selama ini tidak atau belum pernah melakukan pengemasan produk apapun. Ketika pelatihan diberikan, mitra sangat antusias bahwa menghasilkan produk yang menarik konsumen untuk membelinya adalah dengan membuat kemasan dan label yang menarik. Mitra sangat antusias akan hal ini. Selain pengemasan, mitra juga telah mengetahui bagaimana melakukan labelisasi produk. Selain itu, tim juga mengarahkan mitra untuk tetap memproduksi dan bersedia untuk melakukan legalisasi produk yaitu untuk penerbitan PIRT agar jangkauan pasar lebih luas dan mampu untuk bersaing produk-produk yang dijual di toko-toko ritel.

Hasil yang diperoleh dari pengabdian kepada masyarakat dalam memanfaatkan produk sekunder Minyak Parede menjadi Sambel Kerak Minyak sangat signifikan memberikan pengetahuan dan keterampilan Ibu PKK Desa Latellang. Harapan dari transfer pengetahuan ini, yakni Ibu PKK Desa Latellang menjadi embrio dalam menumbuhkan antusisme masyarakat khususnya pengolah Minyak Parede lainnya dalam memanfaatkan produk 
sekunder yang tidak dimanfaatkan menjadi produk yang memiliki nilai ekonomis tinggi, sehingga menjadi pemicu masyarakat yang pernah mengolah Minyak Parede (belum mengetahui manfaat pengolahan kerak Minyak Parede) untuk mulai kembali antusias sebab transformasi kerak Minyak Parede ternyata mampu menghasilkan produk yang dapat memiliki nilai jual yang tinggi.

\section{KESIMPULAN}

Kesimpulan dari hasil pengabdian kepada masyarakat dalam skema Program Kemitraan Masyarakat ini yang dilaksakana di Desa Latellang sebagai berikut:

- Peran serta mitra dalam melaksanakan PKM ini cukup besar dengan kemampuan mitra by doing sesuai harapan tim melalui strategi society parcipatory.

- Peningkatan pengetahuan dan keterampilan mitra cukup signifikan dengan persentase 45$80 \%$.

- Mitra mampu menghasilkan produk Sambel Kerak Minyak dengan melakukan pengemasan dan labelisasi dimana setiap produk Sambel Kerak Minyak dikemas dengan berat bersih 70 gram.

\section{UCAPAN TERIMA KASIH}

Penulis mengucapkan terima kasih kepada DRPM Kemneristekdikti/BRIN dalam pendanaan Program ini serta mitra Ibu PKK Desa Latellang.

\section{DAFTAR PUSTAKA}

Anwar, C., Salima, R. 2016. Perubahan Rendeman dan Mutu Virgin Coconut Oil (VCO) Pada Berbagai Kecepatan Putar dan Lama Waktu Sentrifugasi. Jurnal Teknotan, 10(2), 51-60.

Aprilasani, Z., Adiwarna. 2014. Pengaruh Lama Waktu Pengadukan Dengan Variasi Penambahan Asam Asetat Dalam Pembuatan Virgin Coconut Oil (VCO) Dari Buah Kelapa. KONVERSI, 3(1), 1-12.

Asfar, A.M.I.A., Arifuddin, W., \& Rahman, A. 2019. Pengolahan Kayu Sepang Di Desa Biru Kecamatan Kahu Kabupaten Bone. Jurnal Panrita Abdi, 3(2), 97-104. DOI: 10.13140/RG.2.2.19814.16961

Asfar, A.M.I.A., Rifai, A., Ilham, M., Damayanti, J.D., \& Asfar, A.M.I.T. Pengolahan Ikan Teri Kering Menjadi Abon Asin Gammi. Dinamisia: Jurnal Pengabdian Kepada Masyarakat, 5(1), 176-180.

Azis, T., Olga, Y., Sari, A.P. 2017. Pembuatan Virgin Coconut Oil (VCO) Dengan Metode Penggaraman. Jurnal Teknik Kimia, 23(2), 129-136.

Haerani. 2010. Pemanfaata Limbah Virgin Coconut Oil (Blondo). Jurnal MKMI, 6(4), 244-248.

Karaouw, S., Santoso, B., Maskromo, I. 2019. Teknologi Pengolahan Minyak Kelapa dan Hasil Ikutannya. Jurnal Litbang Pertanian, 38(2), 86-94.

Latipah, N., Syarifuddin. 2019. Keterampilan Mahasiswa dalam Membuat Produk Olahan Berbahan Dasar Buah Kelapa. IJIS Edu: Indonesian J. Integr. Sci. Education, 1(2), 115-124.

Marlina., Wijayanti, D., Yudiastari, I.P., Safitri, L. 2017. Pembuatan Virgin Coconut Oil Dari Kelapa Hibrida Menggunakan Metode Penggaraman Dengan Nacl dan Garam Dapur. Jurnal Chemurgy, 1(2), 7-12.

Muharun., Apriyantoo, M. 2014. Pengolahan Minyak Kelapa Murni (VCO) Dengan Metode Fermentasi Menggunakan Ragi Tape Merk NKL. Jurnal Teknologi Pertanian, 3(2), 9-14.

Nurlia., Asfar, A.M.I.T., Asfar, A.M.I.A., Rahayau, A.S., Nurwahyuni., \& Ridwan, M.I. Pemanfaatan Tempurung Kelapa, Tongkol Jagung dan Sekam Padi Sebagai Pesetisida Ramah Lingkungan. Prosiding Seminar Nasional Pengabdian Kepada Masyarakat, Universitas Lancang Kuning Tahun 2020. 
Salam, A.H., Syahrizal. 2018. PKM-Pengusaha Arang Tempurung Kelapa Desa Bantan Air Kabupaten Bengkalis. Dinamisia-Jurnal Pengabdian Kepada Masyarakat, 2(2), 278-282.

Yasser, M. Asfar, AMIA., Asfar, AMIT., Rianti, Marlia., Budianto, Eko. 2020. Pengembangan Produk Olahan Gula Merah Tebu dengan Pemanfaatan Ekstrak Herbal di Desa Latellang Kabupaten Bone. Jurnal Panrita Abdi, 4(1), 42-51.

Yuniwati, M. 2018. Pemberdayaan Wanita Di Desa Sedayu Magelang Melalui Keterampilan Memproduksi Virgin Coconut Oil (VCO). Jurnal Dharma Bakti-LPPM IST AKPRIND Yogyarakarta, 1(2), 151-160. 